\title{
Effect of Protecting Proteins From Degradation in the Rumen and Replacing Percentages of Treated Proteins with Formaldehyde on Biochemical Blood Parameters of Al Awassi Lambs
}

\author{
Ibrahim S. Jasim \\ Scholar Researcher, Prime Minister Advisory Commission, Baghdad, Iraq
}

\begin{abstract}
The present experiment was carried out to investigate the effect of different percentages (50 and 100\%) of dried whey powder and sun flower meal treated with blood or formaldehyde on Biochemical blood parameters: Blood Glucose (BG), Blood Urea Nitrogen (BUN), Blood Cholesterol (BCH), Blood Total Protein (BTP), Blood Albumin (ALB) and Blood Globulin (GLO) in lambs fattening diets. The results showed insignificant effect in $(\mathrm{BG}),(\mathrm{BUN}),(\mathrm{BCH}),(\mathrm{BTP}),(\mathrm{ALB})$ and $(\mathrm{GLO})$ for dried whey powder treated with blood or formaldehyde compared sun flower meal treated with blood or formaldehyde, while there was significant increase $(\mathrm{P}<0.05)$ in $(\mathrm{BTP})$ and insignificant effect in $(\mathrm{BG}),(\mathrm{BUN}),(\mathrm{BCH}),(\mathrm{ALB})$ and (GLO) for dried whey powder treated with formaldehyde in percentages $100 \%$ compared sun flower meal treated with formaldehyde in percentages $100 \%$, and for dried whey powder treated with formaldehyde in percentages $50 \%$ compared sun flower meal treated with formaldehyde in percentages $50 \%$.
\end{abstract}

Key words : dried whey powder, sun flower meal, blood, formaldehyde, Biochemical blood parameters.

\section{Introduction}

Increasing the degradation protein in the rumen beyond the permissible limit in the ruminant diets increases the level of $\mathrm{NH}_{3}-\mathrm{N}$ in the rumen, which leads to its increase in the blood ${ }^{(1)}$. The increase in the level of undegradable protein in the rumen leads to an increase in the level of glucose in the blood due to the increase in the flow of amino acids into the duodenum due to the decrease in the degradation of dietary protein, which leads to the provision of greater quantities of the base material used in the processes of synthesis of glucose by Gluconeogenesis ${ }^{(2,1,16)}$. Nutrition of a high percentage of sources of undegradable protein in the rumen led to a decrease in BUN ${ }^{(3)}$, the level of ammonia in the rumen, increase of BUN due to reduced absorbed ammonia that enters the liver to convert to urea ${ }^{(4)}$. In what is considered Lipid content or tissue catabolism are indicators of blood cholesterol level ${ }^{(5)}$. ${ }^{(12)}$ reported that the level of blood cholesterol was significantly increased as a result of reduced degradation in dietary protein, ${ }^{(6)}$ and the level of muscle tissue destruction (7) influencing the level of Total proteins, albumin and globulin in the blood.

The third largest source of protein used for ruminants feed after soybean and canola seedling ${ }^{(19)}$. The protein of the sun flower is characterized by its solubility and high decomposition compared to the other protein sources. Therefore, there are obstacles to meet the needs of highyielding dairy cows, calves and fast-growing sheep because the protein is rapid decomposition in the rumen, producing peptides, amino acids and ammonia, which reduces the degree of utilization and loss of amino acidsand low digestibility ${ }^{(20)}$.

Whey was considered a non-conventional, fast degradable protein source, it is a byproduct of cheese making process of milk, containing $7 \%$ solid materials consisting of $4.9 \%$ lactose, $0.6 \%$ ash, low amounts of fat acid and protein (15-20\%) and most whey is eliminated as a neglected product, so the challenge for nutritionists is to find the best way to benefit from it ${ }^{(21,17)}$. 


\section{Materials and Methods}

Treatment of the sun flower meal or dried whey powder with fresh blood

Blood was collected from ruminants that were slaughtered in the Karkh massacre in containers containing citrate of sodium $(6.8 \mathrm{~g} / \mathrm{L}$ blood $)$. The blood was then added to the sun flower or dried whey powder by using an equal weight of blood and weight (1: 1) and then mixed by hand and dried in a fan oven at $60^{\circ} \mathrm{C}$ for 24 hours, after that, the sun flower or dried whey powder was manually broken and packed in bags until it was used $^{(22)}$.

Treatment of sun flower meal or dried whey powder with formaldehyde
The sun flower or dried whey powder was treated with $5 \%$ formaldehyde solution and 1 liter solution/10 $\mathrm{kg}$ dry matter from the sun flower or dried whey powder by sprinkler after brushing the sun flower or dried whey powder over a piece of nylon on the ground in a closed chamber with constant flipping to ensure that the solution reaches all parts of the sunflower or dried whey powder to obtain a homogeneous level of treatment. The formaldehyde sun flower or dried whey powder was kept in tightly sealed nylon bags and left for 72 hours for interaction between formaldehyde and sunflower meal or dried whey powder. The bags and their contents were then emptied onto a nylon piece inside a well-ventilated hall for 48 hours to allow for the volatilization of the unformed formaldehyde solution, then the sunflower or dried whey powder was put in bags until it was used ${ }^{(18)}$.

\begin{tabular}{|c|c|c|c|c|c|c|c|}
\hline $\begin{array}{c}\text { Feeding } \\
\text { materials }\end{array}$ & Barley & $\begin{array}{l}\text { Wheat } \\
\text { barn }\end{array}$ & $\begin{array}{c}\text { Sunflower } \\
\text { treated with } \\
\text { blood }\end{array}$ & $\begin{array}{c}\text { Sunflower } \\
\text { treated with } \\
\text { formaldehyde }\end{array}$ & $\begin{array}{c}\text { Whey } \\
\text { treated } \\
\text { with blood }\end{array}$ & $\begin{array}{l}\text { Whey treated } \\
\text { with } \\
\text { formaldehyde }\end{array}$ & $\begin{array}{l}\text { Fresh } \\
\text { alfalfa }\end{array}$ \\
\hline Dry matter & 90.12 & 89.87 & 94.77 & 93.30 & 97.59 & 95.86 & 27.22 \\
\hline Organic matter & 93.58 & 91.59 & 89.31 & 85.78 & 96.13 & 94.68 & 91.13 \\
\hline Crude protein & 12.22 & 14.72 & 21.37 & 21.67 & 21.08 & 19.11 & 18.21 \\
\hline Crude fiber & 5.72 & 10.11 & 15.35 & 15.55 & --- & ---- & 27.15 \\
\hline Ether Extract & 3.15 & 4.63 & 9.79 & 10.05 & 7.39 & 8.17 & 3.03 \\
\hline Ash & 6.42 & 8.41 & 8.00 & 8.04 & 6.39 & 6.02 & 8.87 \\
\hline $\begin{array}{l}\text { Nitrogen free } \\
\text { extract }\end{array}$ & 72.49 & 62.13 & 42.42 & 42.44 & 64.32 & 65.82 & 42.74 \\
\hline $\begin{array}{l}\text { Acid detergent } \\
\text { fiber }\end{array}$ & 27.13 & 48.45 & 38.44 & 37.88 & ---- & ---- & 45.75 \\
\hline $\begin{array}{c}\text { Neutral } \\
\text { detergent fiber }\end{array}$ & 6.27 & 14.24 & 26.92 & 27.50 & ---- & ---- & 33.91 \\
\hline Lignin & 1.35 & 2.88 & 9.88 & 10.50 & ---- & ---- & 8.77 \\
\hline Cellulose & 4.92 & 11.36 & 17.04 & 17.00 & ---- & ---- & 25.14 \\
\hline Hemicellulose & 20.86 & 34.21 & 11.52 & 10.38 & --- & ---- & 11.84 \\
\hline $\begin{array}{c}\text { Metabolic } \\
\text { energy (Mica } \\
\text { Gul } / \mathrm{kg} \text { ) }\end{array}$ & 12.7 & 12.3 & 12.7 & 12.7 & 14.1 & 14.2 & 10.2 \\
\hline
\end{tabular}


Table 1 : Chemical composition of raw materials in the installation of concentrates and fresh grit based on dry matter (\%).
Metabolic energy $(\mathrm{Mg} / \mathrm{kg}$ of material as is $)=0.012$ $\times$ crude protein $+0.031 \mathrm{x}$ ether extract $+0.005 \times$ raw fiber $+0.014 \times$ nitrogen-free extract $(23)$.

Table 2 : Chemical analysis of experimental treatments for first experiment based on dry matter.

\begin{tabular}{|c|c|c|}
\hline Type of treatment & \multicolumn{2}{|c|}{ Treatment with formaldehyde } \\
\hline Replacement ratio \% & 50 & 100 \\
\hline Treatments & $\mathrm{T} 3$ & $\mathrm{~T} 4$ \\
\hline \multicolumn{3}{|c|}{ Chemical composition } \\
\hline Dry matter & 98.14 & 97.03 \\
\hline Organic matter & 93.85 & 93.66 \\
\hline Crude protein & 15.28 & 15.44 \\
\hline Crude fiber & 8.29 & 8.81 \\
\hline Ether Extract & 5.10 & 5.56 \\
\hline Ash & 6.14 & 6.34 \\
\hline Nitrogen free extract & 65.18 & 63.85 \\
\hline Acid detergent fiber & 35.20 & 35.61 \\
\hline Neutral detergent fiber & 13.29 & 12.81 \\
\hline Lignin & 2.50 & 2.18 \\
\hline Cellulose & 10.79 & 10.63 \\
\hline Hemicellulose & 21.91 & 22.80 \\
\hline $\begin{array}{l}\text { Metabolic energy } \\
(\text { Mica Gul/kg) }\end{array}$ & 12.9 & 12.8 \\
\hline
\end{tabular}

Metabolic energy $(\mathrm{Mg} / \mathrm{kg}$ of material as is $)=0.012 \times$ crude protein $+0.031 \mathrm{x}$ ether extract $+0.005 \times$ raw fiber $+0.014 \times$ nitrogen-free extract (23). 
Table 3 : Chemical analysis of experimental treatments for Second experiment based on dry matter.

\begin{tabular}{|c|c|c|}
\hline Type of treatment & \multicolumn{2}{|c|}{ Treatment with formaldehyde } \\
\hline Replacement ratio \% & 50 & 100 \\
\hline Treatments & $\mathrm{T} 3$ & $\mathrm{~T} 4$ \\
\hline \multicolumn{3}{|c|}{ Chemical composition } \\
\hline Dry matter & 96.30 & 95.21 \\
\hline Organic matter & 92.09 & 93.58 \\
\hline Crude protein & 15.50 & 15.63 \\
\hline Crude fiber & 8.87 & 8.32 \\
\hline Ether Extract & 5.28 & 5.45 \\
\hline Ash & 7.90 & 6.42 \\
\hline Nitrogen free extract & 62.44 & 64.18 \\
\hline Acid detergent fiber & 35.14 & 36.05 \\
\hline Neutral detergent fiber & 13.22 & 12.65 \\
\hline Lignin & 2.73 & 2.75 \\
\hline Cellulose & 10.49 & 9.90 \\
\hline Hemicellulose & 21.92 & 23.40 \\
\hline $\begin{array}{l}\text { Metabolic energy } \\
\text { (Mica Gul } / \mathrm{kg} \text { ) }\end{array}$ & 12.6 & 12.8 \\
\hline
\end{tabular}

Metabolic energy $(\mathrm{Mg} / \mathrm{kg}$ of material as is $)=0.012$ $\times$ crude protein $+0.031 \mathrm{x}$ ether extract $+0.005 \times$ raw fiber $+0.014 \times$ nitrogen-free extract $(23)$.

\section{Study some blood parameters}

(BG), (BUN), (BCH) , (BTP), (ALB) : was to ${ }^{(25)}$ determined using the Bio System BTS - 350 .

(GLO) : was calculated by subtracting albumin from total proteins.

\section{Chemical analysis}

DM, CP, CF, : was estimated according to ${ }^{(24)}$.
$(\mathrm{OM})$ : was calculated by subtracting the amount of ash from dry matter.

$\mathrm{NFE}:=\mathrm{OM}-(\mathrm{CP}+\mathrm{CF}+\mathrm{EE})$.

(NDF), (ADF) and(ADL): was estimated according

Cellulose : was calculated: ADF - ADL.

Hemicellulose : was calculated: NDF-ADF.

\section{Statistical analysis}

The Statistical Analysis System (26) according 
to (Completely Randomized Design-CRD), The differences between the averages were compared with Test (T).

\section{The mathematical model}

$Y i j=\mu+E i+e i j$

$Y i j=$ the value of the transaction $j$ return to the transaction $i$.

$\mu=$ The general mean of the studied character.

$\mathrm{Ei}=$ It represents two experiences $\mathrm{i}$.

eij $=$ Random error distributed by a normal distribution with an average of 0 and a variance of $\mathrm{o}^{2} \mathrm{e}$.

\section{Results and Discussion}

The level of degradation and digestibility of dietary protein in the rumen affects some parameters of the blood as it is used as an indicator of protein status, especially in qualitative comparisons of protein sources and the level of dietary protein intake ${ }^{(8,9,10)}$.
Effect type of protein treatment with blood or formaldehyde on Biochemical blood parameters.

Table 4 showed that there were insignificant effect in (BG), (BUN), (BCH), (BTP), (ALB) and (GLO) for dried whey powder treated with blood or formaldehyde compared sun flower meal treated with blood or formaldehyde, This may be due to the fact the difference between the protein type ${ }^{(13,14)}$ did not affect the level of blood glucose, as these results agreed with ${ }^{(6,16)}$. While the results did not agree with ${ }^{(15)}$ who stated that increasing the level of undegradable protein in the rumen with an increase in the substitution ratio of dried whey powder treated with blood or formaldehyde leads to an increase in the level of (BG) due to an increase in the flow of amino acids into the duodenum, to decrease the solubility of dissolution Dietary protein, which leads to greater quantities of the matrix used in the gluconeogenesis process ${ }^{(3,2,17)}$. And these results agreed with ${ }^{(8,9,16)}$ Regarding (BUN), (BCH), (BTP), (ALB) and (GLO).

Table 4 : Effect type of protein treatment with blood or formaldehyde on Biochemical blood parameters

\begin{tabular}{|c|c|c|c|c|c|}
\hline Studied traits & $\begin{array}{c}\text { dried whey } \\
\text { powder }\end{array}$ & $\begin{array}{c}\text { standard } \\
\text { error }\end{array}$ & sun flower meal & standard error & $\begin{array}{c}\text { Effect } \\
\text { significance }\end{array}$ \\
\hline BG & 68.937 & \pm 0.395 & 68.770 & \pm 0.312 & N.S \\
\hline BUN & 41.375 & \pm 0.351 & 42.145 & \pm 0.313 & N.S \\
\hline BCH & 67.375 & \pm 0.392 & 67.937 & \pm 0.293 & N.S \\
\hline BTP & 6.987 & \pm 0.031 & 6.927 & \pm 0.031 & N.S \\
\hline ALB & 3.355 & \pm 0.026 & 3.340 & \pm 0.021 & N.S \\
\hline GLO & 3.631 & \pm 0.039 & 3.586 & \pm 0.037 & N.S \\
\hline
\end{tabular}

N.S Non significant.

Effect type of protein treatment with formaldehyde in $100 \%$ on Biochemical blood parameters.

Table 5showed that there were significant increase $(\mathrm{P}<0.05)$ in (BTP) whereas insignificant effect in $(\mathrm{BG})$, (BUN), (BCH), (ALB) and (GLO), for diets dried whey powder treated with formaldehyde in $100 \%$ compared diets sun flower meal treated with formaldehyde in $100 \%$, This may be due to the effect of the type of treatment (formaldehyde) in filling the deficiency in the protein profile provided by the microbial protein ${ }^{(6)}$ and the level of muscle tissue destruction ${ }^{(7)}$ that affects the level of total proteins, and this may be due to the nature of the flower gain. The sun flower meal as a protein 
source compared to dried whey powder as its content of fibers and phenolic compounds may affect the level of protection resulting from treatments (11). The percentage of phenolic compounds for sunflower meal treated with formaldehyde $(0.13 \pm 11.02)$ The percentage of fiber for sunflower meal treated with formaldehyde $(0.11 \pm 15.55)$ and there are no phenolic compounds or fibers in dried whey powder (27). As these results agree with ${ }^{(12,2,16)}$, while these results are not in agreement with ${ }^{(14,15,13)}$.

Table 5 : Effect type of protein treatment with formaldehyde in $100 \%$ on Biochemical blood parameters.

\begin{tabular}{|c|c|c|c|c|c|}
\hline Studied traits & $\begin{array}{c}\text { dried whey } \\
\text { powder }\end{array}$ & standard error & sun flower meal & standard error & Effect significance \\
\hline BG & 69.666 & \pm 0.432 & 69.416 & \pm 0.398 & N.S \\
\hline BUN & 41.250 & \pm 0.565 & 41.583 & \pm 0.451 & N.S \\
\hline BCH & 68.666 & \pm 0.619 & 68.666 & \pm 0.449 & N.S \\
\hline BTP & $\mathrm{a} 7.092$ & \pm 0.029 & $b 6.985$ & \pm 0.029 & $*$ \\
\hline ALB & 3.378 & \pm 0.042 & 3.345 & \pm 0.038 & N.S \\
\hline GLO & 3.714 & \pm 0.067 & 3.640 & \pm 0.060 & N.S \\
\hline
\end{tabular}

Different characters within the same column indicate significant differences $(\mathrm{p}<0.05)$; N.S Non significant.

Effect type of protein treatment with formaldehyde in $50 \%$ on Biochemical blood parameters.

Table 6 showed that there were significant increase $(\mathrm{P}<0.05)$ in $(\mathrm{BTP})$ whereas insignificant effect in $(\mathrm{BG})$, $(\mathrm{BUN}),(\mathrm{BCH}),(\mathrm{ALB})$ and $(\mathrm{GLO})$, for diets dried whey powder treated with formaldehyde in $50 \%$ compared diets sun flower meal treated with formaldehyde in $50 \%$, these results agree with ${ }^{(12,2,16)}$, while these results are not in agreement with $^{(14,15,13)}$.

Table 6 : Effect type of protein treatment with formaldehyde in $50 \%$ on Biochemical blood parameters.

\begin{tabular}{|c|c|c|c|c|c|}
\hline Studied traits & $\begin{array}{c}\text { dried whey } \\
\text { powder }\end{array}$ & standard error & sun flower meal & standard error & Effect significance \\
\hline BG & 66.583 & \pm 0.483 & 67.083 & \pm 0.621 & N.S \\
\hline BUN & 43.500 & \pm 0.722 & 43.833 & \pm 0.519 & N.S \\
\hline BCH & 65.416 & \pm 0.398 & 66.250 & \pm 0.462 & N.S \\
\hline BTP & $a 6.850$ & \pm 0.029 & 66.731 & \pm 0.032 & $*$ \\
\hline ALB & 3.380 & \pm 0.039 & 3.294 & \pm 0.037 & N.S \\
\hline GLO & 3.470 & \pm 0.055 & 3.437 & \pm 0.060 & N.S \\
\hline
\end{tabular}

Different characters within the same column indicate significant differences $(\mathrm{p}<0.05)$; N.S Non significant. 


\section{Conclusion}

The treatment of dried whey powder with formaldehyde in100 and $50 \%$ led to a significant increase $(\mathrm{P}<0.05)$ in the level of (BTP) compared to the sun flower meal, while there was no significant effect on the Biochemical blood parameters of the treatment with blood or formaldehyde.

\section{Conflict of Interest: None}

\section{Funding: Self}

Ethical Clearance: Not required

\section{References}

1. Nisa MU, Javaid A, Shahzad MA, Sarwar M. Influence of varying ruminally degradable to undegradable protein ratio on nutrient intake, milk yield, nitrogen balance, conception rate and days open in early lactating Nili-Ravi buffaloes (Bubalus bubalis). Asian-Australasian Journal of Animal Sciences. 2008 Sep 3;21(9):1303-11.

2. Scholljegerdes EJ, Weston TR, Ludden PA, Hess BW. Supplementing a ruminally undegradable protein supplement to maintain essential amino acid supply to the small intestine when forage intake is restricted in beef cattle. Journal of animal science. 2005 Sep 1;83(9):2151-61.

3. Rusche, W.C., R.C. Cochran, L.R. Corah, J.S. Stevenson, D.L. Harmon, R.T. Brandt, Jr., and J.E. Minton. Influence of source and amount of dietary protein on performance, blood metabolites, and reproductive function of Primiparous beef cows. J. Anim . Sci., 1993. 71 : 557-563.

4. Sarwar, M., M.A. Khan and M. Nisa. Effect of organic acids or fermentable carbohydrates on digestibility and nitrogen utilization of urea treated wheat straw in buffalo bulls. Aust. J. Agric. Res., 2004. 55:229-235.

5. Miner, J.L., M.K . Petersen, K.M. Havstad, M.J. McInemey and R.A. Bellow. The effects of ruminal escape protein or fat on nutritional status of pregnant winter-grazing beef cows. Anim. Sci. 1990. 68:1743-1750.

6. Richardel, P.T. Effects of dietary protein level and fish meal on growth and hormonal status of weaned dairy calves. MSc. Thesis, Louisiana State University and Agricultural and Mechanical College. 2004.

7. Lynch, G.P. and C. Jackson. Jr. Metabolic responses of ewes to different protein intakes during late gestation. Can. J. Anim. Sci. 1986. 63:595.

8. Pitts, J.S., F.T. McCollum, and C.M. Britton. Protein supplementation of steers grazing tobosagrass in spring and summer. J. Range Manag. 1992. 45:226-231.

9. Huntington, G.B., E.J. Zetina, J.M. Whitt, and W. Potts. Effects of dietary concentrate level on nutrient absorption, liver metabolism, and urea kinetics of beef steers fed isonitrogenous and isoenergetic diets. J. Anim. Sci. 1996. 74:908-916.

10. Monteils, V., S. Jurjanz and G. Blanchart. Nitrogen utilization by dairy cows fed diet differing in crude protein level with a deficit in ruminal fermentable nitrogen. Reprod. Nutr. Dev., 2002. 42: 545-557.

11. Daiber, K.H. and J.R.N. Taylor. Effect of formaldehyde on protein extraction and quality of high and low. Tanins sorghum. J .Agri. Food Chem. 1982. 30:70-72.

12. Ali, M.F., B. El-Saidy, M.K. Mohsen and M.M.E. Khalafalla. Performance of lambs fed on ration containing soybean meal treated with formaldehyde and probiotics. Ii. Productive and reproductive performance. Egyp. J. Nutr. Feed, 2005.8(1): 511527.

13. Shamoon, M., N. Saleh and N.Y. Abbo. Effects of different levels of protein treated with formaldehyde on nutrients digestibility and some rumen and blood parameters in Awassi sheep. Iraqi J. Vet. Sci., 2009. 23, Supplement II, 169-173.

14. Davis, J.J., T. Shlu, R. Puchala, M.J. Herseiman, S.P. Hart, E.N. Escobar, S.W. Coleman, P. Hoseph and A.L.Goetsch. Effect of bovine somatotropin and ruminally undegraded protein of feed intake, live weight gain and mohair production by yearling angora wethers. J. Anim. Sci. 1999. 77:1029.

15. Salih, A.M. Effect of high percentage of low degradability in the rumen on sheep performance, Ph.D. Thesis, University of Mosul. 2007.

16. Saeed, A.A. Effect of level and degradability of dietary protein fed with or without bakers yeast 
(saccharomyces cervisia) on Turkish awassi lambs performance. Ph.D. litter university of Baghdad / college of agriculture. 2011.

17. Stock, R., T. Klopfenstein, D. Brink, R. Britton and D. Harmon. Whey as a source of rumen degradable protein. II. For Growing Ruminants production. J. Anirn. Sci. 1986. 63:1574.

18. Hassan S A, Al-Ani A N, Al-Jassim R A M and Abdullah NS. Effects of roughage to concentrate rations and rumen undegrable protein supplementation on growth of lambs. Small Ruminant Research 1990.3, 317-324.

19. USDA-FAS. Oilseeds: World Markets and Trade. Available at:https://apps.fas.usda.gov/psdonline/ circulars/oilseeds.pdf. Accessed Aug. 2017.24.

20. Lusus EWC. Sunflower meals and food protein in sunflower Handbook National Sunflower Assn. Bismark, N.D. 1982. pp 26-36.

21. El-Shewy, A. Whey as a feed ingredient for lactating cattle. Sci. Int. 2016. 4: 80-85.

22. Matsumoto $M$, Kobayashi $T$, ltabashi $H$ and Ørskov ER. Investegation of protection of soybean meal and amino acid from rumen degradation with whole blood treatment. Anim. Feed Sci. Techn. 1995.56, 37-43.

23. MAFF. Ministry of Agric., Fisheries and Food Dept., of Agric. And Fisheries for Scotland Energy allowances and Feed systems for ruminants, Technical Bulletin,33. First published. 1975.

24. AOAC. Association of official analytical chemists, official methods of analysis. 14th end. Washington, D.C.,U.S.A. 2005.

25. Goering HK and Van SoestPJ. Foragefiber analysis, U.S. Department of Agriculture, Handbook. 1970. No. 379, 1-20.

26. SAS. Statistical Analysis System, User's Guide. Statistical. Version 9.1th ed. SAS. Inst. Inc. Cary. N.C. USA. 2012.

27. Jasim, Ibrahim Sattar. Effect of Substitution protected whey or sunflower meal with blood or Formaldehyde on Awassi lambs performance. $P h D$ thesis, College of Agriculture Engineering Science , University of Baghdad. 2019. 